\title{
Room Temperature Synthesis and Characterization of Novel Bi(III) Complex with 2-Amino-3- Carbomethoxy-4,5,6,7-Tetrahydrobenzo[B]Thiophene as Potential Antimicrobial Agent
}

\author{
Emmanuel Sopbué Fondjo, ${ }^{1,{ }^{*}}$ Désire André Siéwé, ${ }^{1}$ Jean-de-Dieu Tamokou, ${ }^{2}$ \\ Steve Endeguele Ekom, ${ }^{2}$ Sorel Kamal Dimo Djeukoua, ${ }^{1}$ Giscard Doungmo, ${ }^{3}$ \\ Mallory E. Walters, ${ }^{4}$ Appolinnaire Tsopmo, ${ }^{4}$ Peter F. W. Simon ${ }^{5}$ \\ and Jules Roger Kuiate ${ }^{2}$ \\ ${ }^{1}$ Laboratory of Applied Synthetic Organic Chemistry, Department of Chemistry, Faculty of Science, \\ University of Dschang, P.O. Box 67 Dschang, Republic of Cameroon \\ ${ }^{2}$ Research Unit of Microbiology and Antimicrobial Substances, Department of Biochemistry, Faculty of Science, \\ University of Dschang, PO Box 067 Dschang, Republic of Cameroon \\ ${ }^{3}$ Institut für Anorganische Chemie, Christian-Albrechts-Universität zu Kiel, Max-Eyth-Str. 2, 24118 Kiel, Germany \\ ${ }^{4}$ Department of Chemistry, Carleton University, 1125 Colonel By Drive K1S 5B6, Ottawa, \\ Canada +1-613-520-260 Ext 3122 \\ ${ }^{5}$ Polymer Chemistry Laboratory, Faculty of Live Sciences, Rhine-Waal University of Applied Sciences, Campus Kleve, \\ Marie-Curie Strasse 1, D-47533 Kleve, Germany \\ * Corresponding author: E-mail: sopbue@yahoo.fr (0000-0002-1077-673X)
}

Received: 06-27-2019

\begin{abstract}
A novel bismuth(III) complex with 2-amino-3-carbomethoxy-4,5,6,7-tetrahydrobenzo[b]thiophene (ACTT) as a ligand have been synthesized. The novel complex was characterized on the basis of its IR, NMR, elemental analysis and MS spectral data. It was found that the ligand behaves as a monodentate chelating agent and bonds to the metal ion through the nitrogen atom of the amino group to form the $\left[\mathrm{Bi}^{\mathrm{III}}(\mathrm{ACTT})_{6}\right] \mathrm{Cl}_{3}$ complex. The new complex compound displayed significant antimicrobial activity (MIC $=8-32 \mu \mathrm{g} / \mathrm{mL}$ ) against Bacillus subtilis, Staphylococcus aureus, Escherichia coli, Pseudomonas aeruginosa, Shigella flexneri, Candida albicans, Candida tropicalis and Cryptococcus neoformans.
\end{abstract}

Keywords: Room temperature synthesis; antimicrobial; complexation reaction; 2-aminothiophene; bismuth

\section{Introduction}

Coordination chemistry is gaining more and more attention nowadays due to the increased demand of new compounds with various properties and functionalities. In fact, combining properties of metal ion like magnetic, optic, conductor, oxydoreduction, biological with the one of an organic chelate compound can lead to new hybrid coordination complexes with enhanced functionalities. There- fore, many coordination compounds with properties like antimicrobial, ${ }^{1-4}$ AND-binding, ${ }^{5}$ antiviral, anticancerous, cytotoxic, ${ }^{6}$ anti-inflammatory, ${ }^{7,8}$ analgesic, ${ }^{9}$ antioxidant, ${ }^{10,11}$ optoelectronic, superconductor, non-linear optical (NLO), ${ }^{12,13}$ light emitting device (LED), ${ }^{14,15}$ catalyst, antidiabetic, ${ }^{16,17}$ gas storage, metaloenzyme, ${ }^{18}$ nanoparticles $^{19,20}$ have been reported.

Heavy metal bismuth is found in group $\mathrm{V}$ in the periodic table as the $83 \mathrm{rd}$ element. Beside its heavy metal 
status, bismuth and derived compounds are relatively non-toxic and can be used as green and effective catalyst ${ }^{21,22}$ in many synthetic reactions to replace toxic catalysts such as compounds of mercury, lead, thallium, arsenic, antimony etc. Other properties of bismuth compounds including antimicrobial, ${ }^{23-27}$ cytotoxic, ${ }^{25-30}$ antispermatogenic, ${ }^{31}$ white light emitting diode (WLEDs) ${ }^{32}$ are also extensively reported. 2-aminotetrahydrobenzo[b]thiophene system and their substituted derivatives have attracted a great deal of interest due to their various electronic, ${ }^{33}$ optical, ${ }^{34}$ dyeing, ${ }^{35-37}$ fluorescence ${ }^{38}$ and pharmacological properties..$^{39-41}$ On the other hand, to the best of our knowledge, the title 2-aminothiophene derivative (ACTT) used as ligand in this study has not yet been reported in any coordination reaction with bismuth(III) salt.

For all these reasons, we became interested on the investigation of its coordination behavior with bismuth(III) salts. Our expectation was that novel hybrid compounds resulting from the combination in the same molecular framework of the bismuth(III) ion coordinated to one or more 2-aminothiophene ligand and combining the features of its components will exhibit new and improved interesting biological and functional properties.

\section{Experimental Part}

\section{1. Chemistry}

All the reagents mentioned in this work were purchased from Aldrich and Fluka and were used without further purification. Melting points are corrected and were determined with a STUART SCIENTIFIC Melting Point Apparatus Model SMP3 at a heating rate of $1.5^{\circ} \mathrm{C} /$ min. The TLCs were carried out on Eastman Chromatogram Silica Gel Sheets $(13181 ; 6060)$ with fluorescent indicator. A mixture of ethyl acetate and methylene chloride (1:1) was used as eluent and iodine was used to develop the chromatograms. The IR spectra were measured with a Fourier Transform Infrared spectrometer Bruker Alpha. EIMS spectra were recorded on a double focusing mass spectrometer (Varian MAT 311A). ${ }^{1} \mathrm{HNMR}$ spectra were recorded in DMSO- $\mathrm{d}_{6}$ on a Bruker DRX spectrometer operating at $300 \mathrm{MHz} .{ }^{13} \mathrm{C}$-NMR spectra were recorded in DMSO- $\mathrm{d}_{6}$ on a Bruker DRX spectrometer operating at $399 \mathrm{MHz}$ with TMS used as internal reference. XRD data was collected on a STOE Stadi-p X-ray powder diffractometer (STOE \& Cie GmbH, Darmstadt, Germany) with $\mathrm{Cu} \mathrm{K} \mathrm{K}_{\alpha 1}$ radiation $(\lambda=1.54056 \AA$; Ge monochromator; flat samples) in transmission geometry with a DECTRIS $^{\curvearrowleft}$ MYTHEN $1 \mathrm{~K}$ detector (DECTRIS, Baden-Daettwil, Switzerland). Elemental analyses were performed With a Euro Vector CHNS-O element analyzer (Euro EA 3000) or a vario MICRO Cube (Co. Elementar Analysensysteme).

\section{1. 1. Preparation of 2-amino-3-carbomethoxy- 4,5,6,7-tetrahydrobenzo $[b]$ thiophene (3)}

A mixture of cyclohexanone (50 mmol, $4.9 \mathrm{~g}$ ), methyl cyanoacetate $(50 \mathrm{mmol}, 4.95 \mathrm{~g})$ and sulphur $(55 \mathrm{mmol}$, $1.76 \mathrm{~g})$ in methanol $(80 \mathrm{~mL})$ was stirred using a magnetic plate shaker thermostated at $50-60{ }^{\circ} \mathrm{C}$. Ammonia $(5 \mathrm{~mL})$ was added drop wise during the first $10 \mathrm{~min}$ of the reaction. After $3 \mathrm{~h}$ of reaction, the resulting precipitate $(8.66 \mathrm{~g}$, $82 \%)$ was collected by filtration and crystallized from methanol to yield a yellow powder, mp: $133-135^{\circ} \mathrm{C}$ (Lit. ${ }^{42}$ $127-128^{\circ} \mathrm{C}$ from methanol). IR (neat) $v \mathrm{~cm}^{-1}: 3419,3310$ $\left(-\mathrm{NH}_{2}\right) ; 3153\left(-\mathrm{OCH}_{3}\right) ; 1649(\mathrm{C}=\mathrm{O}) ; 1585,1575(\mathrm{C}=\mathrm{C})$; 775; 734 (C-S); $1332(\mathrm{C}-\mathrm{N}) ; 1268$ (C-O). ${ }^{1} \mathrm{H}-\mathrm{NMR}(400$ $\left.\mathrm{MHz}, \mathrm{DMSO}-\mathrm{d}_{6}\right) \delta_{\mathrm{H}}: 7.17,3.61,2.52,2.46,2.36,1.61$. ${ }^{13} \mathrm{C}-\mathrm{NMR}\left(101 \mathrm{MHz}\right.$, DMSO-d $\left.\mathrm{d}_{6}\right) \delta_{\mathrm{C}}: 165.87,163.41$, 131.83, 115.93, 102.90, 50.77, 26.97, 24.41, 23.34, 22.87. Elemental analysis found (calculated): C: $56.87 \%$ (56.87\%); H: 6.16\% (6.16\%); N: 6.63\% (6.64\%); S: 15.17\% (15.17\%).

\section{1. 2. Preparation of Metal Complex 4}

To a magnetically stirred solution of the ligand 3 $(0.32 \mathrm{~g} ; 1.5 \mathrm{mmol})$ in methanol $(10 \mathrm{~mL})$ a solution of $\mathrm{BiCl}_{3}$ $(0.315 \mathrm{~g} ; 1 \mathrm{mmol})$ in methanol $(10 \mathrm{~mL})$ was gradually added. After $48 \mathrm{~h}$, the product formed was collected by filtration and crystallized from a mixture water/methanol to give $0.39 \mathrm{~g}(82 \%)$ of 4 as brown precipitate; $\mathrm{mp} 112^{\circ} \mathrm{C}$. IR (neat) $v \mathrm{~cm}^{-1}: 3480 ; 3333\left(-\mathrm{NH}_{2}\right) ; 1653(\mathrm{C}=\mathrm{O}) ; 1576 ; 1526$ $(\mathrm{C}=\mathrm{C}) ; 1323(\mathrm{C}-\mathrm{N}) ; 1271$ (C-O). ${ }^{1} \mathrm{H}-\mathrm{NMR}(400 \mathrm{MHz}$, DMSO-d $\left.{ }_{6}\right) \delta_{\mathrm{H}}: 7.93,7.91,7.74,7.72,7.33,7.22,7.09,6.96$, 4.63, 3.78, 3.62, 3.59, 3.58, 3.58, 3.45, 3.44, 3.42, 3.38, 3.37, $3.35,3.33,1.94,1.62,1.19 .{ }^{13} \mathrm{C}-\mathrm{NMR}(101 \mathrm{MHz}, \mathrm{DM}-$ SO-d $\left.{ }_{6}\right) \delta_{\mathrm{C}}: 166.65,165.88,165.17,163.92,163.74,163.41$, $132.03,131.84,130.31,120.99,116.26,115.94,102.06$, $101.30,51.75,51.06,50.95,50.77,27.77,26.98,24.57$, 24.41, 24.26, 24.11, 23.34, 22.87, 18.42. Elemental analysis found (calculated): C: $45.53 \%$ (45.53\%); H: 4.94\% (4.93\%); N: $5.31 \%$ (5.31\%); S: 12.14\% (12.14\%).

\section{2. Biology}

\section{2. 1. Microorganisms}

A total of six bacteria and three yeasts strains were tested for their susceptibility to the studied compounds. The studied microorganisms include Staphylococcus aureus ATCC25923, Escherichia coli S2(1), Bacillus subtilis, Staphylococcus aureus, Pseudomonas aeruginosa ATCC27853, Shigella flexneri SDINT, Candida albicans ATCC10231, Candida tropicalis PK233, Cryptococcus neoformans H99. These microorganisms were taken from our laboratory collection. The bacterial and fungal species were maintained on agar slant at $+4^{\circ} \mathrm{C}$ and subcultured at $37^{\circ} \mathrm{C}$ on nutrient agar (NA, Conda, Madrid, Spain) and Sabouraud Dextrose Agar (SDA, Conda) slants respectively, prior to any antimicrobial test. 


\section{2. 2. Determination of Minimum Inhibitory Concentration (MIC) and Minimum Microbicidal Concentration (MMC)}

MIC values were determined by a broth micro-dilution method as described earlier. ${ }^{43}$ Each test sample was dissolved in dimethyl sulfoxide (DMSO) and the solution was then added to Mueller Hinton Broth (MHB) for bacteria or Sabouraud Dextrose Broth (SDB) for yeasts to give a final concentration of $1024 \mu \mathrm{g} / \mathrm{mL}$. This was serially diluted twofold to obtain a concentration range of $0.25-512 \mu \mathrm{g} /$ $\mathrm{mL}$. Then, $100 \mu \mathrm{L}$ of each concentration were added in each well (96-well microplate) containing $95 \mu \mathrm{L}$ of MHB or SDB and $5 \mu \mathrm{L}$ of inoculum for final concentrations varying from $0.125-256 \mu \mathrm{g} / \mathrm{mL}$. The inoculum was standardized at $1.5 \times 10^{6}$ colony-forming units $(\mathrm{CFU}) / \mathrm{mL}$ for bacteria and $2 \times 10^{5}$ spores $/ \mathrm{mL}$ for yeasts using a spectrophotometer (Jenway ${ }^{\text {tm }} 6305$ UV/Visible Spectrophotometer, Fisher scientific, UK). The negative control well consisted of $195 \mu \mathrm{L}$ of MHB or SDB and $5 \mu \mathrm{L}$ of the standard inoculum. The MICs were assessed visually and were taken as the lowest compound concentration at which there was no growth or virtually no growth. The lowest concentration that yielded no growth after the sub-culturing was considered as the minimum microbicidal concentrations (MMCs). Ciprofloxacin (Sigma-Aldrich, Steinheim, Germany) and nystatin (Merck, Darmstadt, Germany) were used as positive controls for bacteria and yeasts, respectively. All the tests were performed in triplicate.

\section{Results and Discussion}

\section{1. Chemistry}

The thiophene compound 2-amino-3-carbomethoxy-4,5,6,7-tetrahydrobenzo[b]thiophene (ACTT) (3) was prepared by applying one-pot procedure of the second

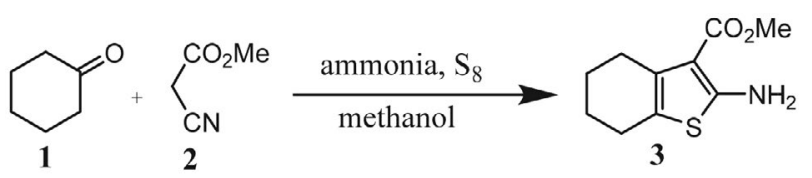

Scheme 1. Reaction sequence to compound 3 version of the Gewald technique, ${ }^{42}$ whereby cyclohexanone (1), methyl cyanoacetate (2) and elemental sulfur were condensed in methanol in the presence of catalytic amount of ammonia (Scheme 1).

The structure of the ligand substrate 3 (ACTT $=$ $\mathrm{CH}_{3} \mathrm{O}_{2} \mathrm{C}-\mathrm{Ar}-\mathrm{NH}_{2}$ ) was confirmed with its physical and spectroscopic data which are in full agreement with those previously reported. ${ }^{42}$

The reaction of compound 3 with bismuth(III) chloride in methanol with constant stirring at room temperature for 48 hours gave the compound $\mathbf{4}$ (Scheme 2).

\section{1. 1. IR spectrum of the Bismuth Complex 4}

The IR bands of the complex 4 were assigned by comparison with the IR spectrum of the starting 2-aminothiophene ligand 3. The elongation frequencies $v\left(\mathrm{NH}_{2}\right)$ of the aromatic amine which were found in the ligand at 3419 $\mathrm{cm}^{-1}$ (more intense) and $3310 \mathrm{~cm}^{-1}$ (more intense) in the ligand, respectively, are shifted to higher frequencies at $3480 \mathrm{~cm}^{-1}$ (shoulder), $3333 \mathrm{~cm}^{-1}$ (shoulder), respectively, in the complex. The presence of these two bands of the amino group in the IR spectrum of the ligand is a clear indication that the complexation occurred without deprotonation of the primary aromatic amine. The modification observed in the shapes of these bands (shoulder) in addition to their important shift $\left(\Delta v=61\right.$ and $\left.23 \mathrm{~cm}^{-1}\right)$ to higher frequencies may be due to the involvement of the corresponding nitrogen atom to the coordination process. ${ }^{4}$ One can also notice that the strong absorption band of the carbonyl function of the carbomethoxy group which appears at $1649 \mathrm{~cm}^{-1}$ in the ligand undergoes a $\Delta v=4 \mathrm{~cm}^{-1}$ shift to higher frequencies and is shown at $1653 \mathrm{~cm}^{-1}$ in the complex. This observation indicates that the oxygen atoms of the carbonyl function of the ester groups of the coordinated 2-aminothiophene ligands are involved in various hydrogen bonds interactions with $-\mathrm{NH}_{2}$ groups.

\section{1. 2. ${ }^{1} \mathrm{H}$ NMR-Spectrum of Complex 4}

Similarly, the ${ }^{1} \mathrm{H}$ NMR signals of compound 4 was assigned by comparison with the ${ }^{1} \mathrm{H}$ NMR spectrum of the ligand 3. In Table 1 the chemical shifts of both compounds are recapitulated. One can also notice here that each signal

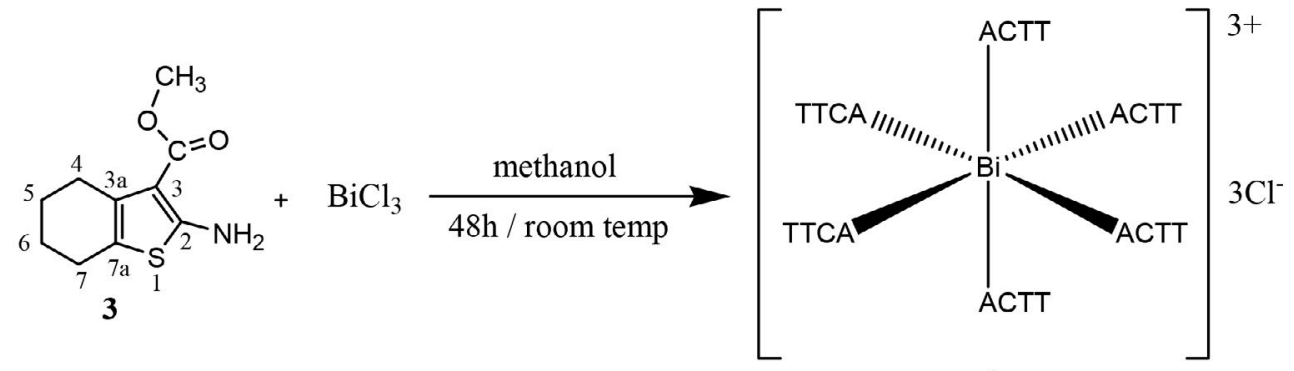

4

Scheme 2. Reaction sequence to $\mathrm{Bi}(\mathrm{ACTT})_{6} \mathrm{Cl}_{3}$ complex 4 
of individual hydrogen or groups of chemically and magnetically equivalent hydrogen atoms in the starting free 2 -aminothiophene ligand $\mathbf{3}$ is splitted into a number of corresponding signals attributed to the six 2 -aminothiophene ligands coordinated to the central bismuth(III) ion.

\section{1. 3. ${ }^{13} \mathrm{C}$ NMR-Spectrum of Complex 4}

The assignments of the ${ }^{13} \mathrm{C}$ NMR signals of compound 4 were made by comparison with the ${ }^{13} \mathrm{C}$ NMR spectrum of the ligand 3. As recapitulated in Table 1, each signal of individual carbon atoms in the starting free 2 -aminothiophene ligand 3 is splitted in a number of corresponding signals attributed to the six ligands coordinated to the bismuth(III) ion in the complex compound 4 .

\section{1. 4. 2D NMR Data of Complex 4 and Ligand 3}

The important interactions found in the ${ }^{1} \mathrm{H},{ }^{1} \mathrm{H}$-COSY; ${ }^{1} \mathrm{H},{ }^{13} \mathrm{C}$-HSQC, ${ }^{1} \mathrm{H},{ }^{13} \mathrm{C}-\mathrm{HMBC}$ and ${ }^{1} \mathrm{H},{ }^{1} \mathrm{H}$-NOESY experiments for compounds $\mathbf{3}$ and $\mathbf{4}$ are recapitulated in Table 2.

The HSQC spectrum (Figure 1) of the ligand shows five correlation spots corresponding to the five carbon atoms bearing protons. Correlation spots are also observed between methoxyl proton at $3.61 \mathrm{ppm}$ and the corresponding carbon at $50.8 \mathrm{ppm}$. The assignment of the $-\mathrm{NH}_{2}$ protons at 7.18 ppm could be rationalized based on the fact that this signal doesn't correlate with any carbon atom. Similar assignments could be done for the complex by comparison (Table 2).

The HMBC experiment shows different correlations' spots that were helpful for the accurate assignments of the

Table 1. Comparison of the ${ }^{1} \mathrm{H}$ and ${ }^{13} \mathrm{C}$ NMR (DMSO- $\mathrm{d}_{6}$ ) chemical shifts of the ligand 3 with those of the complex 4 .

\begin{tabular}{lcccc}
\hline \multirow{2}{*}{$\mathbf{N}^{\circ} \mathbf{C} / \mathbf{H}$} & \multicolumn{2}{c}{ Ligand 3} & \multicolumn{2}{c}{ Complex $\mathbf{4}$} \\
& $\boldsymbol{\delta}_{\mathbf{H}}$ in ppm & $\boldsymbol{\delta}_{\mathbf{C}}$ in ppm & $\boldsymbol{\delta}_{\mathbf{H}}$ in ppm & $\boldsymbol{\delta}_{\mathbf{C}}$ in ppm \\
\hline 2 & - & 102.91 & - & $102.89,102.06,101.30$ \\
3 & - & 131.83 & - & $132.03,131.84,130.31$ \\
$3 \mathrm{a}$ & - & 115.93 & - & $120.99,116.26,115.94$ \\
4 & 1.62 & 22.87 & $1.60,1.66$, & $22.87,18.42$ \\
5 & 2.52 & 26.97 & 2.55 & $27.77,27,76,26.98$ \\
6 & 2.35 & 24.41 & 2.46 & $24.57,24.41,24.26$ \\
7 & 1.62 & 23.34 & $1.60,1.66$ & $24.11,23.34$ \\
$7 \mathrm{a}$ & - & 163.41 & - & $163.92,163.74,163,41$ \\
$\mathrm{C}=\mathrm{O}$ & - & 165.88 & - & $166.65,165.88,165.17$ \\
$-\mathrm{OCH}$ & 3.62 & 50.76 & $4.61,3.78,3.73$, & $51.75,50.95,50.77$, \\
& & & $3.62,3.59,3.44$ & $50.88,50.86,50.68$ \\
$-\mathrm{NH}_{2}$ & 7.18 & - & $7.73,7.22$ & - \\
\hline
\end{tabular}

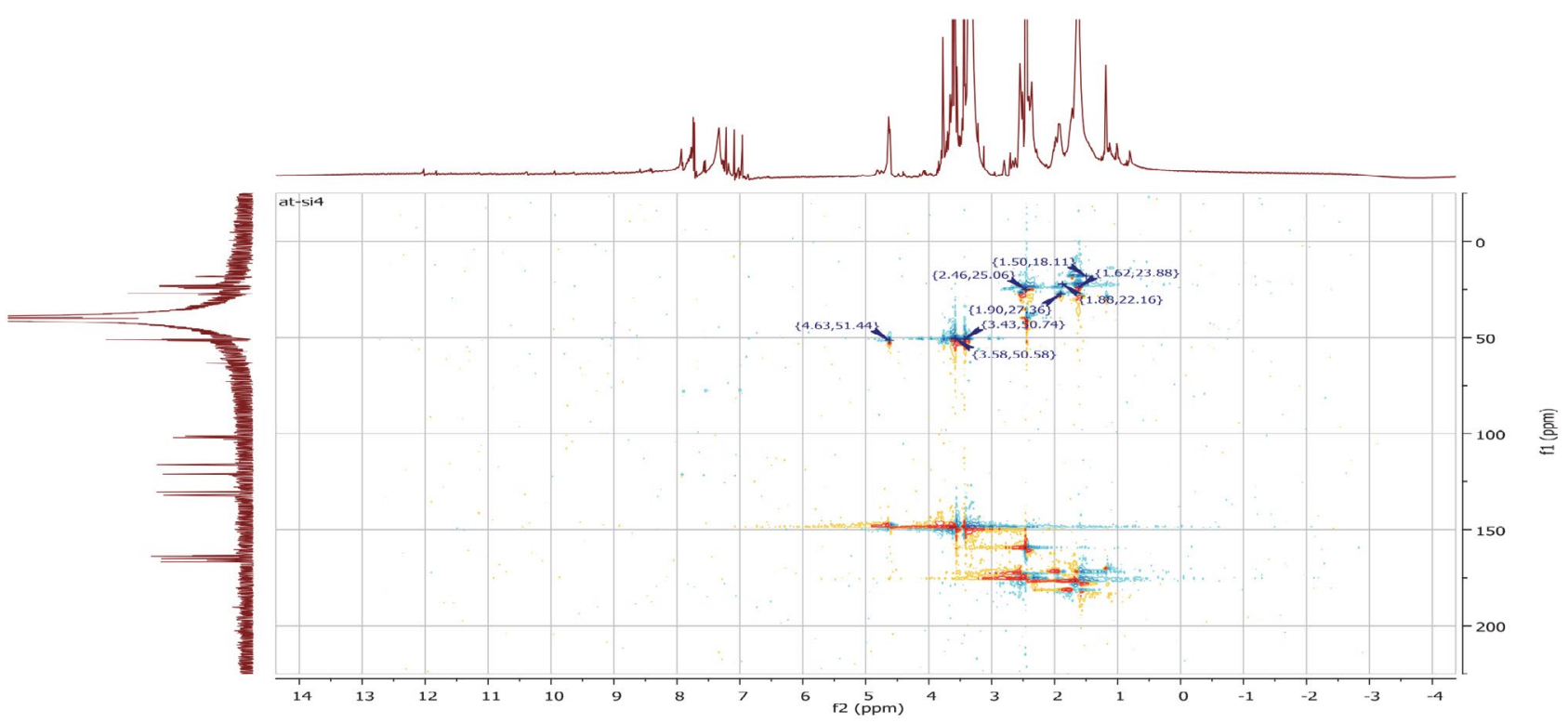

Figure 1. HSQC spectrum of complex with some correlations 


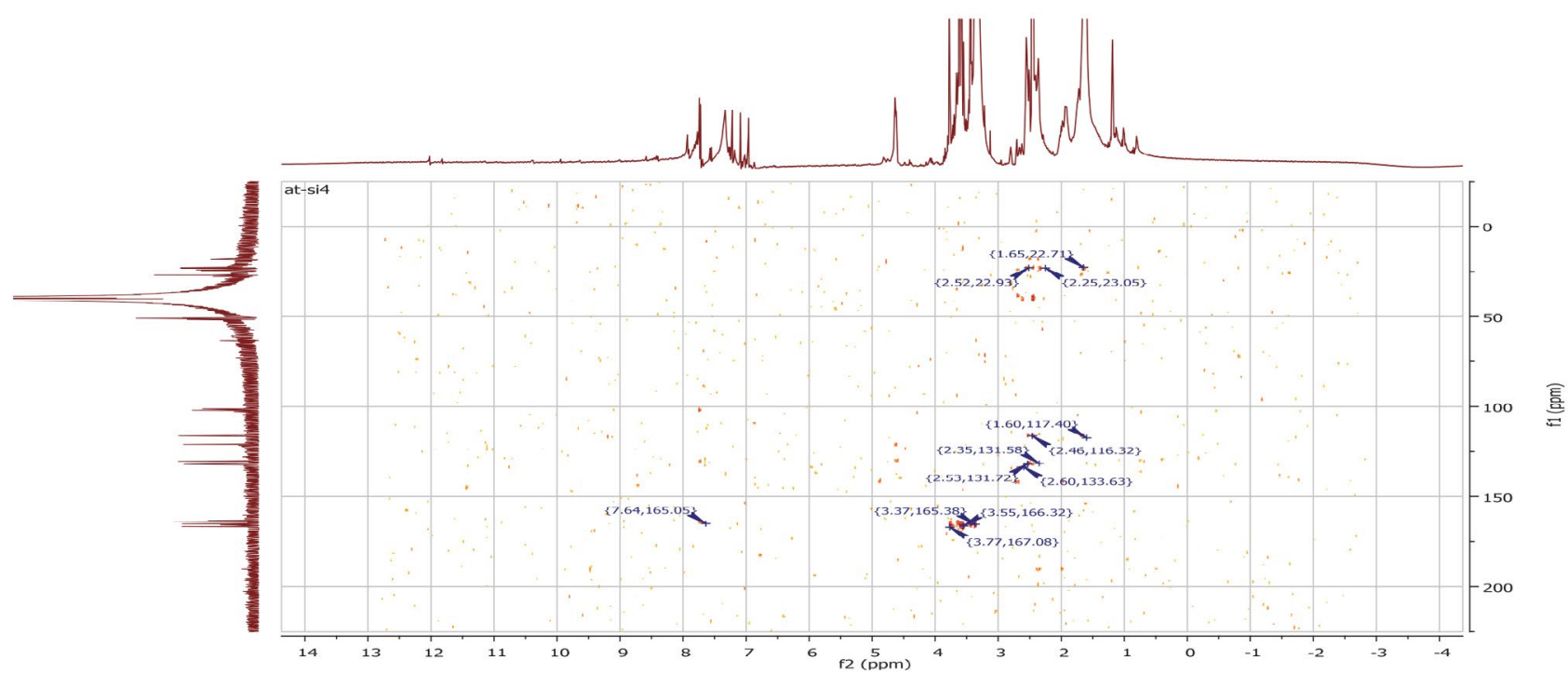

Figure 2. HMBC spectrum of complex with some correlations

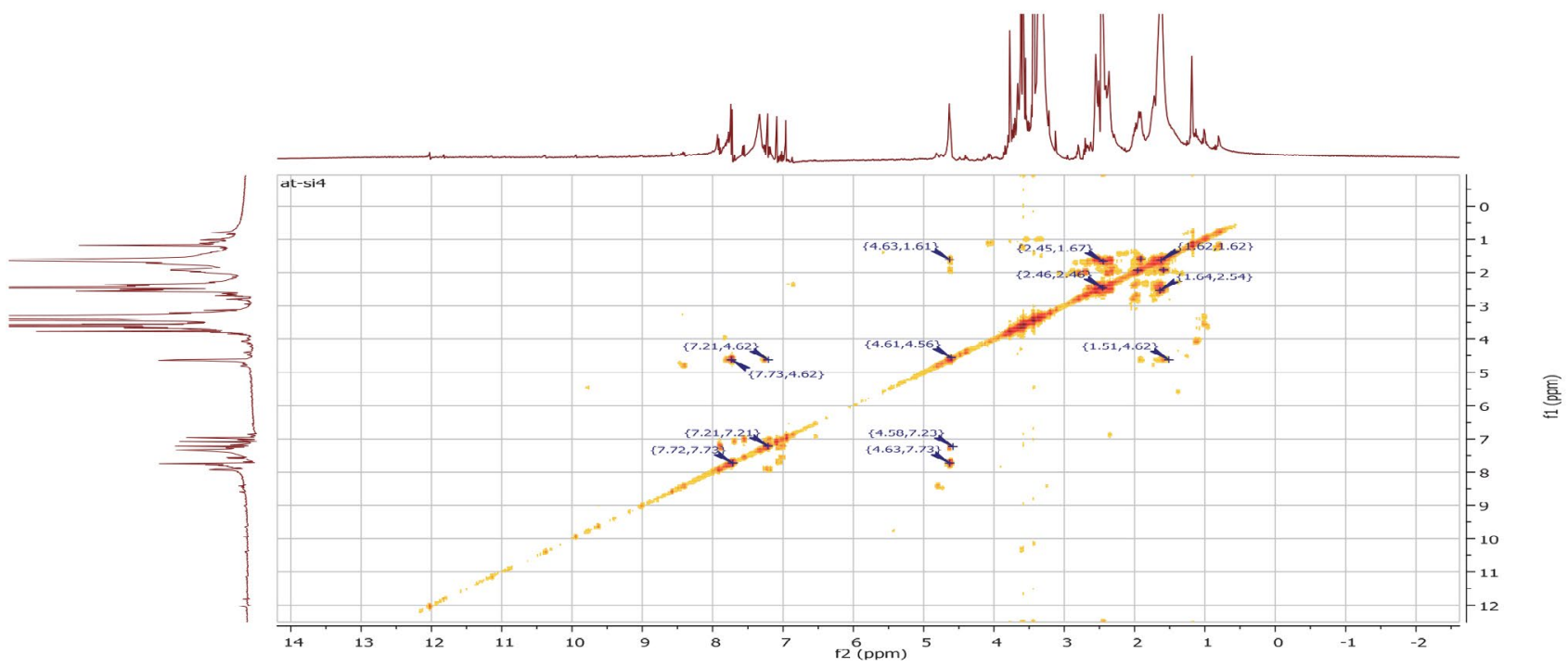

Figure 3. COSY spectrum of complex with some correlations

various carbon atoms in the ligand's molecule (Figure 2). For instance, a correlation between the methoxyl proton appearing at $3.61 \mathrm{ppm}$ and the carbonyl carbon function at $165.9 \mathrm{ppm}$ have been found. Correlations between these methoxyl protons and some carbon atoms of the thiophenic ring at $102.9 \mathrm{ppm}$ have also been observed. A number of these analogous correlations have been found in the HMBC spectrum of compound 4 but their individual assignments to each coordinated ligand could not be conclusive due to high complexity of the overlapping signals caused by the homologous proton systems of the six coordinated ligands.

The COSY experiment of the ligand clearly exhibited the correlation spots between the protons of the cyclohexane ring (Table 2). For the complex (Figure 3), besides the homologous correlations displayed in the COSY experi- ment, a correlation was observed between the methoxyl protons at $4.62 \mathrm{ppm}$ and the amino protons $7.73 \mathrm{ppm}$.

The spatial proximity between the methoxyl group and the amino group is confirmed by the NOESY experiment for the ligand and for the complex as well.

\section{1. 5. Mass Spectrum of Complex 4}

The mass spectrum of compound 4 exhibited characteristic ion fragments such as $\left[\mathrm{Bi}\left(\mathrm{C}_{10} \mathrm{H}_{13} \mathrm{NSO}_{2}\right)_{2}\right]^{3+}(\mathrm{m} / z$ $=630),\left[\mathrm{Bi}\left(\mathrm{C}_{10} \mathrm{H}_{13} \mathrm{NSO}_{2}\right)\right]^{3+}(\mathrm{m} / z=419), \mathrm{Bi}$ (isotope) or $\left(\mathrm{C}_{10} \mathrm{H}_{13} \mathrm{NSO}_{2}\right)^{+}(m / z=210)$, in agreement with the suggested structure.

Furthermore, one can notice the absence of ion fragments such as $[\mathrm{BiCl}]^{+}$or $\left[\mathrm{BiCl}_{2}\right]^{+}$proving that chlorine 
Table 2: Comparison of the interactions in the ${ }^{1} \mathrm{H}$ and ${ }^{13} \mathrm{C}-2 \mathrm{D}-\mathrm{NMR}\left(\mathrm{DMSO}-\mathrm{d}_{6}\right.$ ) spectra of the ligand 3 with those of the complex 4

\begin{tabular}{|c|c|c|c|c|c|c|c|c|c|c|}
\hline $\mathbf{N}^{\circ} \mathbf{C}$ & $\boldsymbol{\delta}_{\mathrm{C}}$ & HSQC & $\begin{array}{c}\text { Ligand } 3 \\
\text { HMBC }\end{array}$ & COSY & NOESY & $\boldsymbol{\delta}_{\mathrm{C}}$ & HSQC & $\begin{array}{c}\text { Complex } 4 \\
\text { HMBC }\end{array}$ & COSY & NOESY \\
\hline 2 & 102.9 & - & $\begin{array}{l}3.62 \\
2.52\end{array}$ & - & - & $\begin{array}{c}102.9 \\
102.6 ; 101.3\end{array}$ & - & 7.74 & - & - \\
\hline 3 & 131.6 & - & $\begin{array}{l}2.52 ; 2,35 \\
\quad 1.62\end{array}$ & - & - & $\begin{array}{c}132.0 \\
131.8 ; 130.3\end{array}$ & - & 2.55 & - & - \\
\hline $3 a$ & 115.9 & - & $\begin{array}{l}2.52 ; 2.35 \\
\quad 1.62\end{array}$ & - & - & $\begin{array}{c}121.0 \\
116.3 ; 116.0\end{array}$ & - & $\begin{array}{l}2.55 ; 2.45 ; \\
1.68 ; 1.65\end{array}$ & - & - \\
\hline 4 & 22.9 & 1.62 & 1.62 & $2.52 ; 2.35$ & - & $22.9 ; 18.4$ & $1.60-1.66$ & $\begin{array}{l}2.45 ; 2.38 \\
2.35 ; 1.65\end{array}$ & $1.92 ; 2.45$ & - \\
\hline 5 & 27.0 & 2.52 & $2.35 ; 1.62$ & 1.62 & - & $\begin{array}{l}27.8 ; 27.8 \\
\quad 27.0\end{array}$ & $\begin{array}{c}2.55 ; 1.90- \\
2.40 ; 1.59\end{array}$ & - & $1.59 ; 1.92$ & - \\
\hline 6 & 24.4 & 2.35 & 1.62 & 1.62 & - & $\begin{array}{c}24.6 ; 24.4 ; \\
24.1\end{array}$ & $\begin{array}{l}2.79 ; 2.69 ; \\
2.65 ; 2.45\end{array}$ & 2.69 & $1.62 ; 1.66$ & - \\
\hline 7 & 23.3 & 1.62 & $\begin{array}{l}2.52 ; 2.35 \\
\quad 1.62\end{array}$ & $2.52 ; 2.35$ & - & 23.3 & $1.60-1.66$ & 2.35 & $1.92 ; 2.45$ & - \\
\hline $7 \mathrm{a}$ & 163.9 & - & - & - & - & $\begin{array}{c}163.9 ; 163.7 \\
163.4\end{array}$ & - & $7.74 ; 7.72$ & - & - \\
\hline $\mathrm{C}=\mathrm{O}$ & 165,9 & - & 3.62 & - & - & $\begin{array}{c}166.7 ; 165.8 \\
165.2\end{array}$ & - & $\begin{array}{l}3.76 ; 4.62 ; \\
3.58 ; 3.55 \\
3.43 ; 3.37\end{array}$ & - & - \\
\hline $\mathrm{OCH}_{3}$ & 50,8 & 3.62 & - & - & 7.18 & $\begin{array}{l}51.8 ; 51.1 \\
51.0 ; 51.0 \\
50.9 ; 50.8\end{array}$ & $\begin{array}{l}3.76 ; 3.58 \\
3.43 ; 4.62 \\
3.55 ; 3.37\end{array}$ & - & 7.72; 7.74; & 7.33 \\
\hline $\mathrm{NH}_{2}$ & - & 7.18 & - & - & 3.62 & - & $7.74 ; 7.72 ; 7.33$ & - & 4.62 & 3.37 \\
\hline
\end{tabular}

atoms are not directly coordinated to the central metal ion in the complex. ${ }^{45}$

\section{1. 7. Powder XRD Study of Compound 4}

$\mathrm{X}$-ray diffraction analysis performed on complex 4 shows a good crystalline structure of the complex formed with well-organized particles (Figure 4). Compound $\mathbf{4}$ has therefore a stable structure in which there is a good cohesion between atoms.

From the above data and based on various literature reports, ${ }^{21,24,46,47}$ we suggest that in compound [Bi(ACTT) ${ }_{6}$ ] $\mathrm{Cl}_{3}(4)$, the bismuth atom exhibits a six-fold coordination to the 2-aminothiophene ligands in a tetragonal bipyramidal geometry. Around the central Bi atom, four $\mathrm{N}$ atoms occupy the equatorial positions and two $\mathrm{N}$ atoms occupy the axial ones. In this representation, the free rotation of the - $\mathrm{Ar}-\mathrm{CO}_{2} \mathrm{CH}_{3}$ fragment of each $\mathrm{N}$-coordinated 2-aminothiophene moiety around the $\mathrm{Cs} p^{2}-\mathrm{N}$ bond enables the formation of various hydrogen bonds between the six oxygen atoms of the carbonyl functions of the six carbomethoxy groups and the hydrogen atoms of the $-\mathrm{NH}_{2}$ group. These interactions are clearly exhibited in the $3 \mathrm{D}$ view of the complex shown in Figure 6.

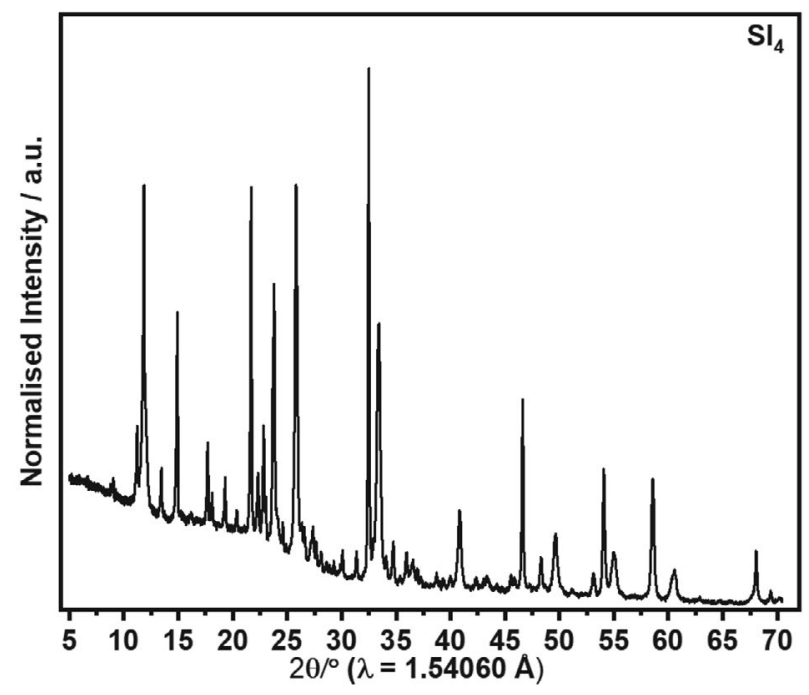

Figure 4. Powder XRD patterns of complex 4.

\section{2. Antimicrobial Activity}

Antimicrobial activity of the ligand, 2-amino-3-carbomethoxy-4,5,6,7-tetrahydrobenzo[b]thiophene (3) and its bismuth complex 4 was examined in vitro against bacterial 


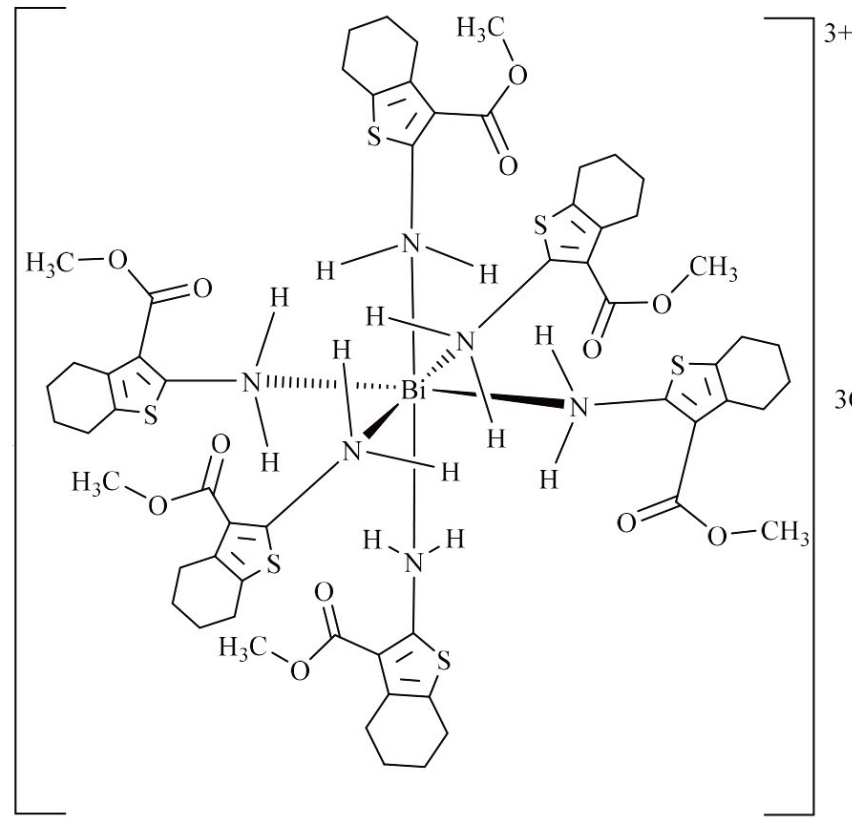

Figure 5. Structural representation of complex 4

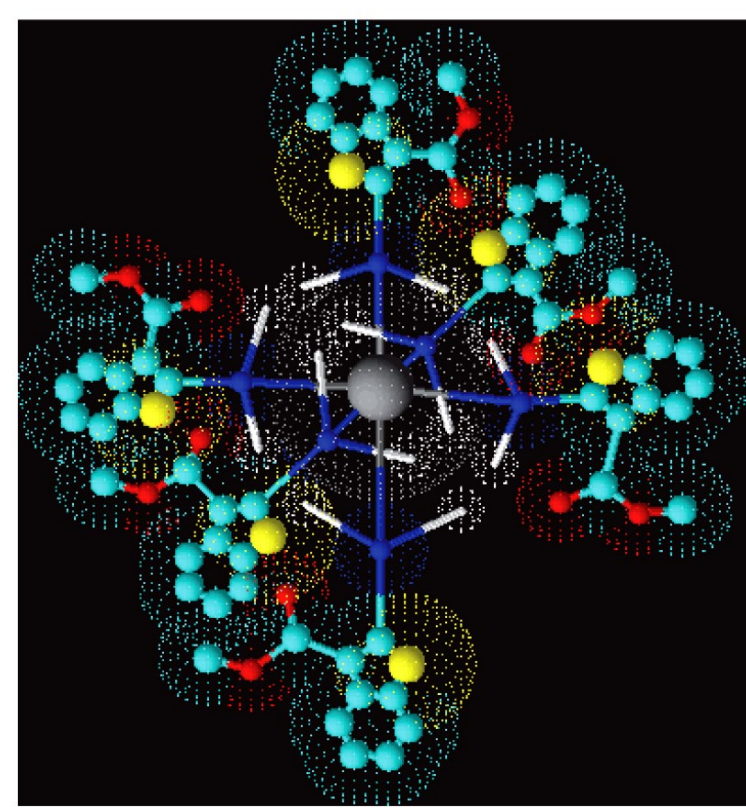

Figure 6. 3D view of the coordination sphere of complex 4 drawn with $\mathrm{ACD} / \mathrm{Labs} 3 \mathrm{D}$ viewer (freeware)

Table 4. Antimicrobial activity (MIC, MBC and MFC in $\mu \mathrm{g} / \mathrm{mL}$ ) of compound complex against bacterial and yeast species

\begin{tabular}{|c|c|c|c|}
\hline Microorganisms & Inhibition & $\begin{array}{c}\text { Compound } 4 \\
\text { parameters }\end{array}$ & $\begin{array}{c}\text { Reference } \\
\text { drugs }^{\star}\end{array}$ \\
\hline Staphylococcus aureus & MIC & 16 & 2 \\
\hline \multirow[t]{2}{*}{ ATCC25923 } & $\mathrm{MBC}$ & 16 & 2 \\
\hline & $\mathrm{MBC} / \mathrm{MIC}$ & 1 & 1 \\
\hline \multirow[t]{3}{*}{ Bacillus subtilis } & MIC & 8 & 8 \\
\hline & MBC & 8 & 1 \\
\hline & $\mathrm{MBC} / \mathrm{MIC}$ & 1 & 4 \\
\hline \multirow[t]{3}{*}{ Staphylococcus aureus } & MIC & 16 & 4 \\
\hline & $\mathrm{MBC}$ & 16 & 4 \\
\hline & $\mathrm{MBC} / \mathrm{MIC}$ & 1 & 1 \\
\hline \multirow[t]{3}{*}{ Pseudomonas aeruginosa ATCC27853 } & MIC & 16 & 2 \\
\hline & $\mathrm{MBC}$ & 32 & 2 \\
\hline & $\mathrm{MBC} / \mathrm{MIC}$ & 2 & 1 \\
\hline \multirow{3}{*}{ Escherichia coli S2(1) } & MIC & 8 & 4 \\
\hline & $\mathrm{MBC}$ & 8 & 4 \\
\hline & $\mathrm{MBC} / \mathrm{MIC}$ & 1 & 1 \\
\hline \multirow[t]{3}{*}{ Shigella flexneri SDINT } & MIC & 32 & 4 \\
\hline & $\mathrm{MBC}$ & 64 & 4 \\
\hline & $\mathrm{MBC} / \mathrm{MIC}$ & 2 & 1 \\
\hline Candida albicans & MIC & 32 & 2 \\
\hline \multirow[t]{2}{*}{ ATCC10231 } & MFC & 32 & 2 \\
\hline & $\mathrm{MFC} / \mathrm{MIC}$ & 1 & 1 \\
\hline \multirow[t]{3}{*}{ Candida tropicalis PK233 } & MIC & 32 & 4 \\
\hline & MFC & 32 & 4 \\
\hline & MFC/MIC & 1 & 1 \\
\hline \multirow[t]{3}{*}{ Cryptococcus neoformans $\mathrm{H} 99$} & MIC & 32 & 4 \\
\hline & MFC & 64 & 4 \\
\hline & MFC/MIC & 2 & 1 \\
\hline
\end{tabular}

${ }^{*}$ Ciprofloxacin for bacteria and nystatin for yeasts; MIC: Minimum Inhibitory Concentration; MBC Minimum Bactericidal Concentration; MFC: Minimum Fungicidal Concentration. 
and fungal species (Table 4). No activity was noticed for the 2-aminothiophene ligand against all the tested microorganisms (results not shown). However, the bismuth(III) complex showed different degrees of antimicrobial activities against the tested fungal and bacterial species (Table 4).

The bismuth complex showed antibacterial activities against all the tested microorganisms (MIC $=8-32 \mu \mathrm{g} /$ $\mathrm{mL})$. The lowest MIC value for this compound $(8 \mu \mathrm{g} / \mathrm{mL})$ corresponding to the best antimicrobial activity was obtained on B. subtilis and E. coli. Interestingly, the antibacterial activity of the complex (MIC $=8 \mu \mathrm{g} / \mathrm{mL}$ ) on $B$. subtilis was found to be equal to that of ciprofoxacin (MIC $=8 \mu \mathrm{g}$ / $\mathrm{mL}$ ) used as reference drugs; highlighting its good antibacterial potency. The least sensitive microorganism was Shigella flexneri SDINT with the highest MIC $(32 \mu \mathrm{g} / \mathrm{mL})$ and MBC $(64 \mu \mathrm{g} / \mathrm{mL})$ values recorded.

The complex compound was more active against bacterial species (MIC $=8-32 \mu \mathrm{g} / \mathrm{mL}$ ) than against yeast strains (MIC $=32 \mu \mathrm{g} / \mathrm{mL}$ ). The findings of the present study showed that the antimicrobial activities varied with the bacterial and fungal strains. These variations may be due to genetic differences between the microorganisms.

The MBC and MFC values obtained were four fold less than their corresponding MIC values; indicating that this compound has microbicidal effect against the tested microorganisms. ${ }^{48}$ The antimicrobial activity of compound $\mathbf{4}$ is in agreement with recent findings by Nur Amirah Jamaluddin et al. and Latika Dawara et al. respectively, ${ }^{23,28}$ who reported the antimicrobial activities of some bismuth(III) complex derivatives against a wide range of microorganisms including Staphylococcus aureus, Bacillus subtilis, Escherichia coli.

\section{3. Effects of Chelation to the Activity of Compounds Complex}

Biological screenings' results show that the 2-aminothiophene ligand which was initially non-active yielded a compound with much better biological profile after the complexation with the bismuth. Chelation is certainly responsible of these new properties. Obviously, the polarity of the metal ion will be reduced to greater extent on chelation, due to the overlap of the ligand orbital and partial sharing of the positive charge of the metal ion with donor groups. ${ }^{49}$ The complexation further increases the delocalization of $\pi$-electrons over the whole chelating ring which may facilitate the penetration of the complexes into lipid membranes and the blocking of the metal binding sites in the enzymes of microorganisms. ${ }^{44}$ It may be hypothesized that there are other factors such as solubility, conductivity and bond length between the metal and ligand which also increase the activity. ${ }^{50}$

\section{Conclusion}

In summary, we have synthesized and characterized a coordination complex containing $\mathrm{Bi}(\mathrm{III})$ with 2 -ami- no-3-carbomethoxy-4,5,6,7-tetrahydrobenzo [b] thiophene at room temperature. Powder XRD confirm the crystalline nature of the complex obtained. Antimicrobial screening's results showed that complex obtained was less antifungal than antibacterial in reference to standard drug, whereas the ligand was found inactive. However, the antibacterial activities of complex on B. subtilis were found to be equal to that of ciprofoxacin used as reference drug; highlighting its good antibacterial potency. The overall results of this study indicated that this novel coordination compound exhibited prominent antibacterial and antifungal activities.

\section{Acknowledgements}

Emmanuel Sopbué Fondjo gratefully acknowledges the financial support from DAAD (grant $\mathrm{N}^{\circ}$ 91691265). Additional financial supports for the work were obtained from the University of Dschang's research grant committee and the Cameroonian Ministry of Higher Education special research allocation.

\section{References}

1. S. Bootwala, M. Tariq, S. Somasundaran, K. Aruna, Int. J. Pharm. Bio. Sci. 2013, 3, 345-354.

2. A. K. M. Nur Alam Siddiki, Md. S. Rahman, M. A. Rahman, Md. A. Salam, A. Salam, Md. A. Yousuf, Md. F. Islam, Md. A. Arafat, Bangladesh Pharm. J. 2012, 15, 83-87.

3. K. Y. Gupta, C. S. Agarwal, P. S. Madnawat, R. Narain, Res. J. Chem. Sci. 2012, 2, 68-71.

4. A. D. Kulkarni, S. A. Patil, P. S. Badami, Int. J. Electrochem. Sci. 2009, 4, 717-729.

5. P. S. Bhava, P. Tharmaraj, V. Muthuraj, M. Umadevi, Int. J. Eng. Sci. 2013, 2, 16-25.

6. R. Gomathi, A. Ramu, Int. J. Innov. Res. Sci. Eng. Technol. 2013, 2, 4852-4865.

7. W. Rehman, M. K. Baloch, A. Badshahb, S. Ali, J. Chin. Chem. Soc. 2005, 52, 231-236. DOI:10.1002/jccs.200500034

8. Md. A. Hossain, Md. C. Sheikh, S. K. M. Al Zaheri, Md. A. Alam, Int. J. Sci. Tech. Res. 2013, 2, 233-237.

9. M. R. Karekal, V. Biradar, M. B. H. Mathada, Bioinorg. Chem. Appl. 2013, 2013, 1-16. DOI:10.1155/2013/315972

10. A. A. Al-Amiery, A. A. H. Kadhum, A. B. Mohamad, Bioinorg. Chem. Appl. 2012, 2012, 1-6. DOI:10.1155/2012/795812

11. M. Iyanar, C. Muthamizhchelvan, S. Ponnusamy, J. T. J. Prakash, Rec. Res. Sci. Tech. 2010, 2, 97-100.

12. S. Cynthia, B. M. Boaz, Int. J. Eng. Sci. Invent. 2013, 2, 38-43.

13. N. T. Kalyani, S. J. Dhoble, R. B. Pode, Adv. Mat. Lett. 2011, 2, 65-70. DOI:10.5185/amlett.2010.10169

14. Y. Kim, F. W. M. Vanhelmont, C. L. Stern, T. Hupp, J. Inorg. Chim. Acta 2001, 318, 53-60.

DOI:10.1016/S0020-1693(01)00400-5

15. P. I. Tripathi, M. M. Kumar, K. Arti, M. Chinmayi, T. Ruchita, S. L. Kant, P. K. Bihari, Res. J. Chem. Sci. 2013, 3, 54-59. 
16. R. Shukla, V. Barve, S. Padhyeb, R. Bhonde, Bioorg. Med. Chem. Lett. 2004, 14, 4961-4965. DOI:10.1016/j.bmcl.2004.07.020

17. B. S. Hammes, M. T. Kieber-Emmons, J. A. Letizia, Z. Shirin,

C. J. Carrano, L. N. Zakharov, A. L. Rheingold, Inorg. Chim. Acta 2003, 346, 227-238. DOI:10.1016/S0020-1693(02)01338-5

18. A. Samadi-Maybodi, S. K. H. Nejad-Darzi, R. Akhoondi, Int. Nano Lett. 2011, 1, 52-58. DOI:10.9734/ACSJ/2014/12703

19. E. Rasu, Am. Chem. Sci. J. 2014, 4, 983-991. DOI:10.9734/ACSj/2014/12703

20. Suresh, J. S. Sandhu, Rasayan J. Chem. 2011, 4, 73-85.

21. A. A. Frutos, L. F. Sala, G. M. Escandar, M. Devillers, J. M. S. Peregrın, M. G. Sierra, Polyhedron 1999, 18, 989-994. DOI:10.1016/S0277-5387(98)00384-2

22. P. Mishra, Int. J. ChemTech Res. 2009, 1, 401-419.

23. N. A. Jamaluddin, I. Baba, N. Ibrahim, J. Anal. Sci. 2014, 18, 251-259.

24. I. I. Ozturk, C. N. Banti, N. Kourkoumelis, M. J. Manos, A. J. Tasiopoulos, A. M. Owczarzak, M. Kubicki, S. K. Hadjikakou, Polyhedron 2014, 67, 89-103.

DOI:10.1016/j.poly.2013.08.052

25. L. - Z. Zhang, G. - Y. An, M. Yang, M. - X. Li, X. - F. Zhu, Inorg. Chem. Commun. 2012, 20, 37-40.

DOI:10.1016/j.inoche.2012.02.009

26. M. Li, Y. Lu, M. Yang,Y. Li, L. Zhang, S. Xie, Dalton Trans. 2012, 41, 12882-12887. DOI:10.1039/c2dt31256e

27. M. - X. Li, L. - Z. Zhang, M. Yang, J. - Y. Niu, J. Zhou, Bioorg. Med. Chem. Lett. 2012, 22, 2418-2423.

DOI:10.1016/j.bmcl.2012.02.024

28. L. Dawara; S. C. Joshi, R. V. Singh, Int. J. Inorg. Chem. 2012, 1-9. DOI:10.1155/2012/372141

29. N. Zhang, Y. Tai, M. Li, P. Ma, J. Zhao, J. Niu, Dalton Trans. 2014, 43, 5182-5189. DOI:10.1039/c4dt00077c

30. Y. Fang, Y. - T. Wang, M. Zhao, Y. - L. Lu, M. - X. Li, Y. - H. Zhang, Polyhedron 2018, 155, 254-260.

DOI:10.1016/j.poly.2018.08.049

31. A. C. Wibowo, S. A. Vaughn, M. D. Smith, H.-C. Z. Loye, Inorg. Chem. 2010, 49, 11001-11008. DOI:10.1021/ic1014708

32. K.-T. Wong, R.-T. Chen, Tetrahedron Lett. 2002, 43, 33133317. DOI:10.1016/S0040-4039(02)00520-8

33. V. T. Dubinina, D. V. Dyumaeva, S. A. Trashin, M. V. Sedova, A. B. Karpo, V. I. Krasovskii, L. G. Tomilova, Macroheterocycles 2012, 5, 149-156. DOI:10.6060/mhc2012.120678d

34. F. A. Mohamed, E. A. El-Alfy, J. Appl. Sci. Res. 2013, 9, 178-183.
35. H. R. Maradiya, Turk. J. Chem. 2001, 25, 441-450. DOI:10.1515/labm.2001.25.11-12.450

36. H. Z. Shams, R. M. Mohareb, M. H. Helal, A. M. El-Sayed, Molecules 2011, 16, 6271-6305.

DOI:10.3390/molecules16086271

36. S. A. Khan, A. Y. Obaid, L. M. Al-Harb, M. N. Arshad, A. M. Asiri, M. B. Hursthouse, Int. J. Electrochem. Sci. 2015, 10, 2306-2323. DOI:10.3390/molecules16086271

38. C. S. Lakshmeeshaa, K. R. V. Reddyb, S. Mohan, Arch. Appl. Sci. Res. 2011, 3, 556-561.

39. A. Mobinikhaledi, M. Kalhor, L. Taheri, Asian J. Chem. 2010, 22, 7399-7404.

40. R. R. Zaky, A. M. Abdelghay, Res. J. Pharm. Bio. Chem. Sci. 2011, 2, 757-764.

41. G. Saravanan, V. Alagarsamy, C. R. Prakash, Int. J. Pharm. Pharm. Sci. 2010, 2, 83-86.

42. G. M. Reinecke, A. T. Woodrow, J. Org. Chem. 1992, 57, 1018-1021. DOI:10.1021/jo00029a046

43. J. D. D. Tamokou, M. F. Tala, H. K. Wabo, J. R. Kuiate, P. Tane, J. Ethnopharmacol. 2009, 124, 571-575.

DOI:10.1016/j.jep.2009.04.062

44. S. S. Patil, M. M. Shaikh, Acta Pol. Pharm.-Drug Res. 2012, 69, 679-686.

45. W. Henderson, J. S. McIndoe, Mass Spectrometry of Inorganic, Coordination and Organometallic Compounds: Tools-Techniques-Tips, Chichester, UK: John Wiley \& Sons, 2005. DOI: $10.1002 / 0470014318$

46. M. K. Kim, V. Jo, S. K. Kim, I. -W. Shim, K. Min Ok, Bull. Korean Chem. Soc. 2008, 29, 2273-2276.

47. B. G. Sukhov, S. A. Mukha, I. A. Antipova, S. A. Medvedeva, L. I. Larina, N. N. Chipanina, O. N. Kazheva, G. V. Shilov, O. A. Dyachenko, B. A. Trofimov, Arkivoc 2008, viii, 139-149.

48. M. G. Djouossi, J. D. D. Tamokou, D. Ngnokam, J. -R. Kuiate, L. A. Tapondjou, D. Harakat, L. Voutquenne-Nazabadioko, BMC Complementary Altern. Med. 2015, 15, 1. DOI: org/10.1155/2013/315972 8. DOI:10.1186/s12906-015-0660-1

49. M. Thankamony, K. Mohanan, Indian J. Chem. 2007, 46A, 247-251.

50. M. Rizzotto, in: Bobbarala V (Eds.), A Search for Antibacterial Agents, InTech, Croatia, 2012, pp. 80-81.

DOI: $10.5772 / 1085$

\section{Povzetek}

Sintetizirali smo nov bizmutov(III) kompleks z 2-amino-3-karbometoksi-4,5,6,7-tetrahidrobenzo[b]tiofenom (ACTT) kot ligandom. Spojina je bila okarakterizirana na podlagi IR, NMR, elementne analize in MS. Ligand je enovezno koordiniran na kovinski ion preko dušikovega atoma ter vodi do nastanka kompleksa $\left[\mathrm{Bi}^{\mathrm{III}}(\mathrm{ACTT})_{6}\right] \mathrm{Cl}_{3}$. Spojina izkazuje izrazito protimikrobno aktivnost (MIC $=8-32 \mu \mathrm{g} / \mathrm{mL}$ ) proti Bacillus subtilis, Staphylococcus aureus, Escherichia coli, Pseudomonas aeruginosa, Shigella flexneri, Candida albicans, Candida tropicalis in Cryptococcus neoformans.

Except when otherwise noted, articles in this journal are published under the terms and conditions of the Creative Commons Attribution 4.0 International License 